\title{
Utilization of ICT by the Users of Arts and Science Colleges in Thiruvarur District - A Study
}

\author{
Aravind $\mathrm{S}$ and Kavitha $\mathrm{R}$ \\ ${ }^{1}$ Librarian and Head, Central Library and Department of Library and Information \\ Science, G.T.N. Arts College (Autonomous), Dindigul, India \\ ${ }^{2}$ Department of Library and Information Science, Mother \\ Teresa Women's University, Kodaikanal, Dindigul District, India \\ Corresponding author email: aragtn2601@yahoo.com
}

\section{ABSTRACT}

This is the age of information dominated by the Digital Technology. The Digital Technology has influenced all aspects of human life. Education is not an exception. Now the technology is in the process of change from Digital to Photon. Shortly Photonic Technology will be available for the use of the society. On the present majority of devices are based on Digital Technology. One such device is the Computer. The Computer is an electronic device that has the capacity to store, retrieve \& process both qualitative \& quantitative information fast and accurately. The computers were never developed for improving quality of the teaching - learning process. But researchers started using Computers for teaching purpose. It gave birth to Computer Assisted Instruction (CAI), Computer Managed Instruction (CMI), Computer Based Instruction (CBI), etc. People started developing CAI for teaching different subjects at the school as well as Higher Education level. The present study aims to find out the utilization of ICT by the users of arts and science colleges in Thiruvarur District. A samples of 116 library users selected randomly were studied. Primary data were collected by using a structured interview scheduled. Percentage analysis and Chi-square test were applied. The findings and observations are the result and outcome of the interpretations made during the study of analysis.

KEY WORDS: INFORMATION COMMUNICATION TECHNOLOGY, COMPUTER ASSISTED INSTRUCTION, COMPUTER MANAGED INSTRUCTION AND COMPUTER BASED INSTRUCTION

\section{INTRODUCTION}

Networking of computers gave birth to Information Technology (IT). UNESCO considered Information Technology as "Scientific, technological and engineering disciplines and management techniques used in information handling and processing, their application, computers and their interaction with men and machines, and associated social, economical and cultural matters". According to Smith \& Campbell (1982), a mosaic of

Biosc Biotech Res Comm P-ISSN: 0974-6455 E-ISSN: 2321-4007

\section{crossef}

Identifiers and Pagination

Year: 2021 Vol: 14 No (5) Special Issue

Pages: 225-230

This is an open access article under Creative

Commons License Attribn 4.0 Intl (CC-BY).

DOI: http://dx.doi.org/10.21786/bbrc/14.5/41 technologies, products and techniques have combined to provide new electronic dimensions to information management. This mosaic is known by the name of Information Technology. OECD (1987) treated Information Technology as "a term used to cover technologies used in the collection, processing and transmission of information. It includes micro-electronics and info-electronic based technologies incorporated in many products and production processes and increasingly affecting the service sector. It covers inter alias computers, electronic office equipment, telecommunication, industrial robot and computer controlled machine, electronic components and software products."

IT was limited only to the textual mode of transmission of information with ease and fast. But the information not only in textual form but in audio, video or any other media is also to be transmitted to the users. Thus, the ICT $=$ IT + Other media. It has opened new avenues,

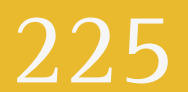


like, Online learning, e-learning, Virtual University, e-coaching, e-education, e-journal, etc. Third Generation Mobiles are also part of ICT. Mobile is being used in imparting information fast and cost effective. It provides e-mail facility also. One can access it anywhere. It will be cost effective. The ICT brings more rich material in the classrooms and libraries for the teachers and students. It has provided opportunity for the learner to use maximum senses to get the information. It has broken the monotony and provided variety in the teaching learning situation.

The students understand better, if they do some practices related to the concept. It makes learning easy and interesting. Laboratory helps in developing a scientific temper. But the fact is that practical are not done by each student in each school. There are many schools which do not have a laboratory. Sometime if the laboratory is available, the instrument is not available. The students are not given freedom to do experiments on their own. Some good schools have laboratories all classes right from class I to XII. They allow students to play with the material available in the laboratory under the supervision of a teacher. The teachers also make use of laboratories during their teaching. At a higher level, the schools are asked not have practical where in animals are used. Animals based practices are done in Biology. In short, there are many restrictions under which the students have to work in the laboratory. Now it is possible to have Virtual laboratory. Once the Virtual Laboratory is developed, it can provide lots of freedom to students. The students can manipulate any attribute or variable related to the experiment and can see how it affects the outcome. Suppose a student wants to study the factors that can affect the focal length of a mirror.

At present in the real laboratory, the student cannot manipulate many variables that he thinks might be related. But Virtual laboratory can provide lots of freedom to the student. That is, student can take different types and shapes of objects, change the distance between the mirror and object to any extent, change the thickness of the mirror, etc. and can see how such attributes affect the focal length of the mirror. The Virtual Laboratory can be developed using ICT. It may be made available at the doorstep of each and every student by uploading it on the Website. Further, each country can think of the developing science website which should give access to Virtual Laboratory and it must be free of cost. Such a Web site will not only help Indian students, but can go a long way in helping students of Underdeveloped and developing countries.

The digital technology has broken the foundries between countries. Human beings do not feel any type of restriction in communicating with people all over the globe. The access has become easier. It is a well-known fact that all students do not understand all subjects to the same extent. Some students find subjects, like, Mathematics, Physics, English, Chemistry, Accountancy, etc. difficult. All educational institutions do have well equipped laboratories and qualified \&t competent Faculty.
Consequently, students do feel the need of academic support out of the school. Therefore, students go for tuition. These days' students from USA \&t other countries are enrolled in private tuition classes in India.

That is they are being taught Online. This has become possible only due to ICT. In Online tutoring the student stays at his home. He logs into his tutor through the use of the Internet and software. He can see the teacher who is in India and the teacher can see the student who is in the USA. The student asks the question and teacher replies it by writing on soft board or using power point presentation. This interaction is normally one to one. It has made the academic life of many students easy. This is how the manpower available in India can be made use of other countries. Not only Online Tutoring but some of the students do outsource their assignments. These assignments are completed by the teachers of other countries. Of course, academically it is not correct because the purpose of giving assignment is not achieved. The student does not develop academically and he may become weak in the subject. All this is happening just because of ICT.

Review of Literature: Islam (2017) stated that the application of web-based information retrieval trends of researchers is ever increasing and the electronic material will eventually replace the traditional library and users need not go there to find and collect information they need.

Gulbahar, Y., \&t Guven, I. (2018). Turkey has been undertaking many projects to integrate Information and Communication Technology (ICT) sources into practice in the teaching-learning process in educational institutions. This research study sheds light on the use of ICT tools in primary schools in the social studies subject area, by considering various variables which affect the success of the implementation of the use of these tools. A survey was completed by 326 teachers who teach fourth and fifth grade at primary level. The results showed that although teachers are willing to use ICT resources and are aware of the existing potential, they are facing problems in relation to accessibility to ICT resources and lack of inservice training opportunities. Aravind and Vinod (2019) conducted a survey ICT has grown up as the most popular and effective information tools of present age. In this study, the usage of ICT by the students of MS Ramaiah Institute of Technology, Bangalore is conceded. A total number of 207 respondents were selected and their response was obtained with the help of questionnaires. Most of the students use the ICT for education purposes and for checking E-mails. Slow access speed and over lode information produced by the internet are the two problems faced by the users.

Archibong, Ijeoma Aniedi, David OtuEffiom (2019) conducted a survey which explored ICT usage and challenges among academic staff. Thus, the main purpose of this study was to determine the areas of ICT usage among academic staff; identify the obstacles to their ICT usage and identify their areas of training need in ICT 
usage. Five research questions were posed to guide this study and a questionnaire was designed to collect data from a sample size of 80 academic staff. From the results, academic staff indicated that ICT is of much help to them in the areas of upgrading of knowledge, research and publication. Weak infrastructure, financial constraints and lack of access to ICT facilities were identified as the major obstacles to ICT usage among academic staff. Furthermore, designing of new learning activities, electronic presentation of materials and making use of the internet were identified as their areas of train need in ICT usage. Recommendation made include providing compulsory free, adequate training opportunity for academic staff by the university management.

\section{Objectives of the Study}

1. To study the personal profile of the respondents.

2. To Study the awareness of ICT based resources among the respondents.

3. To find the adequacy of accessing ICT based resources.

4. To study the purpose and usefulness of accessing ICT based resources among the respondents.

5. To identify the method of acquiring IT Skills by the respondents.

6. To identify the problem faced by the respondents.

7. To determine the level of satisfaction among the respondents

\section{METHODOLOGY}

The survey method is adopted the present study. The primary data for research has been collected from the respondents through a well-structured questionnaire based on the objectives of the present study. Data collection the questionnaire was distributed to faculty members of arts and science colleges, Thiruvarur District. Totally 123 questionnaires was distributed and received only from 116 respondents. The simple percentage and chi-square test are used for further analysis.

Table 1. Use of ICT based Resources and Services

\begin{tabular}{|l|c|c|c|}
\hline S.NO & $\begin{array}{c}\text { Types of E- } \\
\text { Resources }\end{array}$ & $\begin{array}{c}\text { No of } \\
\text { respondents }\end{array}$ & $\%$ \\
\hline 1 & CD-ROM & 51 & 19.24 \\
\hline 2 & Internet & 80 & 30.18 \\
\hline 3 & OPAC & 14 & 5.28 \\
\hline 4 & Online database & 30 & 11.32 \\
\hline 5 & E-Journals & 45 & 16.98 \\
\hline 6 & E-book & 29 & 10.94 \\
\hline 7 & Audio Cassettes & 12 & 4.53 \\
\hline 8 & Video & 4 & 1.51 \\
\hline Total & 265 & 100 & \\
\hline
\end{tabular}

Note: Because of multiple choice options the percentage is proceed with more than 100\%

\section{Limitations of the Study}

- Only students and faculties of Arts and Science colleges, Thiruvarur District were included in the study, hence the findings cannot generalize to other population.

- Since the Sample is not large enough, the findings of the study cannot be generalized to all students and faculties of Arts and Science colleges, Thiruvarur District.

- In this study only few personal variables have been related to ICT usage of the respondents.

\section{ANALYSIS AND DISCUSSIONS}

Table shows the use of ICT based resources and services. The maximum number of $80(30.18 \%)$ of respondents are using the internet, followed by 51 (19.24\%) of respondents use E-journals, 45 (16.98\%) of respondents use CD-ROM, 30 (11.32\%) of respondents use online database, 29 (10.94\%) of respondents use E-books, 14 (5.28\%) of respondents use the OPAC, 12 (4.53\%) of respondents audio cassettes and 4 (1.51\%) respondents use Video. It could be seen clearly from the above discussion that a maximum number of 80 (30.18\%) of respondents use inter.

\begin{tabular}{|c|c|c|c|}
\hline S.NO & $\begin{array}{l}\text { Electronic } \\
\text { Resources }\end{array}$ & $\begin{array}{c}\text { No of } \\
\text { respondents }\end{array}$ & $\%$ \\
\hline 1 & For research / study & 85 & 35.71 \\
\hline 2 & For communication & 39 & 16.38 \\
\hline 3 & Finding relevant information & 43 & 18.06 \\
\hline 4 & For career development & 46 & 19.33 \\
\hline 5 & Other activities & 25 & 10.51 \\
\hline & Total & 238 & 100 \\
\hline
\end{tabular}

Note: Because of multiple choice options the percentage is exceeded by more than 100\%

From the table, it is clear that 85 (35.71\%) of respondents are using ICT based resources and services for the purpose of their research/ study while 46 (19.33\%) of respondents using for career development, 43 (18.06\%) of respondents are using electronic resources for finding relevant information, 39 (16.38\%) of respondents are using for communication purpose and 25 (10.51\%) of respondents are using electronic resources for other activities. It could be seen clearly from the above discussion that, a maximum number of 85 respondents are using electronic resources for research/ study.

Table shows the most popular method of acquiring the necessary skill to use ICT based resources and Services ,80(30.88\%) of respondents are learned through selfthought, while $63(24.32 \%)$ of respondents are learned through trial and error,42(16.22\%) of respondents each acquired skill from external course,31(11.96\%)of 
respondents are learned from computer, staff,22(8.49\%) of respondents and learned guidance from others ,12(4.63\%) of respondents are learned from library staff and $9(03.48 \%)$ of respondents are learned from course offered by in situation. Table indicates that preference of using search engines, It could be noted that $72(27.16 \%)$ of Respondents are using yahoo, followed by 60 (22.64\%) of respondents use Google, 30 (11.32\%) of respondents use info seek, 29 (10.94\%) of respondents use Alta vista, 26 (9.81\%) of respondents use Lycos (stick), 06 (2.26\%) of respondents use Ask.com, and 05 (1.88\%) of respondents use excite to access the information in the internet's. It is seen from the above discussion that, the majority of the respondents use yahoo to access the information in the internet.

Table 3. Learned to ICT based Resources and Services

\begin{tabular}{|c|c|c|c|}
\hline S.NO & $\begin{array}{c}\text { Learned to } \\
\text { E-Resources }\end{array}$ & $\begin{array}{c}\text { No of } \\
\text { respondents }\end{array}$ & $\%$ \\
\hline 1 & Trail an Error & 63 & 24.32 \\
\hline 2 & Guidance from Others & 22 & 8.49 \\
\hline 3 & Self-Taught & 80 & 30.88 \\
\hline 4 & Guidance from Library Staff & 12 & 4.63 \\
\hline 5 & Course Offered by Institution & 09 & 3.47 \\
\hline 6 & External Course & 42 & 16.22 \\
\hline 7 & Guidance from (Computer) & 31 & 11.96 \\
\hline & Staff & 259 & 100 \\
\hline
\end{tabular}

Note: Because of multiple choice options the percentage is exceeded by more than $100 \%$

Table 4. Preference of using search engines

\begin{tabular}{|c|c|c|c|}
\hline S.NO & $\begin{array}{c}\text { Search } \\
\text { engines }\end{array}$ & $\begin{array}{c}\text { No of } \\
\text { respondents }\end{array}$ & $\%$ \\
\hline 1 & Google & 60 & 22.64 \\
\hline 2 & Yahoo & 72 & 27.16 \\
\hline 3 & Info seek & 30 & 11.32 \\
\hline 4 & Lycos & 26 & 9.81 \\
\hline 5 & Alta vista & 29 & 10.94 \\
\hline 6 & MSN & 32 & 12.07 \\
\hline 7 & Ask.Com & 06 & 2.26 \\
\hline 8 & Excite & 05 & 1.88 \\
\hline 9 & ERNET & 05 & 1.88 \\
\hline & Total & 265 & 100 \\
\hline
\end{tabular}

Note: Because of multiple choice options the percentage is exceeded to more than $100 \%$

Table shows the $96(28.83 \%)$ of respondents stated that access to up to date information as a benefit of using ICT based resources and Services, followed by 90 $(27.03 \%)$ and $87(26.13 \%)$ of respondents stated that
ICT based Resources and Services helps faster access to information and easier access to information respectively and $60(18.02 \%)$ of respondents found that access to a wider range of information an advantage of using ICT based Resources and Services. It could be seen clearly from the above discussion that, a maximum number of respondents that stated that access to up to date information as a benefit of using ICT based Resources and Services.

Table 5. Impact of ICT based Resources and Services on academic development

\begin{tabular}{|l|c|c|c|}
\hline S.NO & $\begin{array}{c}\text { Impact of E } \\
\text { Resources }\end{array}$ & $\begin{array}{c}\text { No of } \\
\text { respondents }\end{array}$ & $\%$ \\
\hline 1 & $\begin{array}{c}\text { Access to Current up to } \\
\text { date information }\end{array}$ & 96 & 28.83 \\
\hline 2 & Easier access to information & 87 & 26.13 \\
\hline 3 & Faster access to information & 90 & 27.03 \\
\hline 4 & Access to wider range & 60 & 18.02 \\
\hline \multicolumn{2}{|c|}{ Total } & 333 & 100 \\
\hline \multicolumn{2}{|c|}{$\begin{array}{l}\text { Note: Because of multiple choice options the percentage is } \\
\text { exceeded to more than 100\% }\end{array}$} \\
\hline \multicolumn{3}{|c|}{} \\
\hline
\end{tabular}

Table 6. Hindrance of access ICT based Resources and Services.

\begin{tabular}{|c|c|c|c|}
\hline $\begin{array}{l}\text { S. } \\
\text { NO }\end{array}$ & Hindrance & $\begin{array}{c}\text { No of } \\
\text { Respondent }\end{array}$ & $\%$ \\
\hline 1 & $\begin{array}{c}\text { Too Much Information } \\
\text { Retrieved }\end{array}$ & 95 & 26.02 \\
\hline 2 & Time Consuming & 69 & 18.90 \\
\hline 3 & $\begin{array}{l}\text { Limited Access to a } \\
\text { Computer Terminal }\end{array}$ & 70 & 19.17 \\
\hline 4 & $\begin{array}{l}\text { Lack of IT Knowledge to } \\
\text { Effectively Utilize the Service }\end{array}$ & 71 & 19.45 \\
\hline 5 & $\begin{array}{c}\text { Using Electronic Resource } \\
\text { often Detracts from } \\
\text { Doing work }\end{array}$ & 60 & 16.44 \\
\hline & Total & 365 & 100 \\
\hline
\end{tabular}

It is noted that in the table, that $95(26.02 \%)$ of respondents stated that too much of information retrieved is the main barrier to access electronic resources, 71(19.45\%) of respondents stated that lack of IT knowledge and electronic resources, 70(19.17\%) of respondents opinion that limited access to a computer terminal hindered to access electronic resources 69 (18.90\%) of respondents stated that is time consuming and $60(16.44 \%)$ of respondents stated that the electronic resources detracts from their work respectively. It is seen from the above 
discussion that, a maximum number of respondents stated that too much of information retrieved is the main barrier to access electronic resource.

Table 7. Chi square test for College of the respondent and frequency of library visit

\begin{tabular}{|l|l|c|c|}
\hline & Value & Df & $\begin{array}{c}\text { Asymp. } \\
\text { Sig. } \\
\text { (2-sided) }\end{array}$ \\
\hline Pearson Chi-Square & $2.166^{\mathrm{a}}$ & 2 & .339 \\
\hline Likelihood Ratio & 2.105 & 2 & .349 \\
\hline Linear-by-Linear & 1.093 & 1 & .296 \\
\hline Association & & & \\
\hline N of Valid Cases & 116 & & \\
\hline
\end{tabular}

Table 8. College wise distribution of respondents and Quantum of time spent in the Library.

\begin{tabular}{|l|l|l|c|}
\hline & Value & Df & $\begin{array}{c}\text { Asymp. } \\
\text { Sig. } \\
\text { (2-sided) }\end{array}$ \\
\hline Pearson Chi-Square & 5.817 & 2 & .213 \\
\hline Likelihood Ratio & 5.596 & 2 & .231 \\
\hline Linear-by-Linear & 1.040 & 1 & .308 \\
\hline $\begin{array}{l}\text { Association } \\
\text { N of Valid Cases }\end{array}$ & 116 & & \\
\hline
\end{tabular}

Table 9. College wise distribution of respondents and preference of library materials.

\begin{tabular}{|l|l|l|c|}
\hline & Value & Df & $\begin{array}{c}\text { Asymp. } \\
\text { Sig. } \\
\text { (2-sided) }\end{array}$ \\
\hline Pearson Chi-Square & $.917^{\mathrm{a}}$ & 2 & .922 \\
\hline Likelihood Ratio & .909 & 2 & .923 \\
\hline Linear-by-Linear & .304 & 1 & .582 \\
\hline $\begin{array}{l}\text { Association } \\
\text { N of Valid Cases }\end{array}$ & 116 & & \\
\hline
\end{tabular}

Table 10. College wise distribution of respondent's opinion about ICT Based Resources and Services

\begin{tabular}{|l|l|c|c|}
\hline & Value & Df & $\begin{array}{c}\text { Asymp. } \\
\text { Sig. } \\
\text { (2-sided) }\end{array}$ \\
\hline Pearson Chi-Square & $4.593^{\mathrm{a}}$ & 2 & .101 \\
\hline Likelihood Ratio & 4.894 & 2 & .087 \\
\hline Linear-by-Linear & 1.290 & 1 & .256 \\
\hline Association & & & \\
\hline N of Valid Cases & 300 & & \\
\hline
\end{tabular}

There is no statistically significant relationship found between the college of the faculty belongs and frequency of library visits ( $\mathrm{X} 2=2.166 \mathrm{df}=2 \mathrm{p}=0.339)$. So, irrespective of the college, the visiting to the library is the same among the faculty members. There is no significant relationship found between the college of the faculty belongs and the quantum of time spent in the library $(\mathrm{X} 2=5.817 \mathrm{df}=2 \mathrm{p}=0.213)$.So, irrespective of the college, the time spent in the library is the same among the faculty members. There is no significant relationship found between the selected college faculty and their preference levels in accessing the library materials in the respective colleges ( $\mathrm{X} 2=14.19 \mathrm{df}=2 \mathrm{p}=0.922)$. Hence, it is shown that there is no variation in the preferred levels of library materials among the selected college faculties. There is no statistically significant relationship found between the college of the faculty belongs and the opinion about the available materials in the library $(\mathrm{X} 2=4.593 \mathrm{df}=2 \mathrm{p}=0.101)$. So, irrespective of the college, the visiting to the library is the same among the faculty members.

\section{CONCLUSION AND IMPLICATIONS}

On the basis of the findings of the study undertaken, the following suggestions are listed for the surveyed libraries. User friendliness should be the top most consideration in the library management. Library staff should periodically undergo for training courses on the use library software fro the better service. It is also suggested that more number of OPAC terminals are needed within the campus. Although the cataloguing system of the select libraries is comparatively encouraging, however, further improvements are required. New recruitments should be done keeping in view the proficiency in handling the automation project.

Technology has had and will perhaps continue to have a dramatic impact on library operations and services. It is the main force for changing the core work culture of library situation. The trends in technology will certainly find their way into large academic library set up. Because, the libraries must satisfy the expectations of their end users to sustain their goal, objective and existence in present techno-oriented world. The first effort for computerization of library work started in the early 1970sin India. However, it has been seen that Indian academic libraries gained significant momentum during the last decade in automating their functions and services. Presently, the large libraries of Indian University colleges are automating their entire library systems operations and services. But, the library staff and user community, particularly in academic universities still limited knowledge in this regard.

Therefore, improving he service quality of the library profession and creating sufficient awareness and interest in adopting the ICT tools among the faculty members are the high priority agenda in higher education. Enhancing the end user experience in the library will bring lots of new innovations in the research and higher learning. 


\section{REFERENCES}

Aravind S and Vinod Kumar B (2019), Aware and Usage of Information Communication Technology among the MS Ramaiah Institute of Technology, Bangalore: A Study. Indian Journal of Information Sources and Services, 9 (2); 122-124.

Archibong, Ijeoma Aniedi, \&t David Out Effiom (2019). ICT in University Education: Usage and Challenges among Academic Staff, 3(2); 404-414.

Baikady, M. R., \&tMudhol, M. V. (2013). Utilization of Web Resources at the Medical College Libraries in Coastal Karnataka. SRELS Journal of Information Management, 50(1); 61-91.

Bediang, G., Stoll, B., Geissbuhler, A., Klohn, A. M., Stuckelberger, A., Nko'o, S., \&tChastonay, P. (2013). Computer literacy and E-learning perception in Cameroon: the case of Yaounde Faculty of Medicine and Biomedical Sciences. BMC Medical Education, 13(1); 57.doi:10.1186/1472-6920-13-57
Gulbahar, Y., Guven, I., Gulbahar, Y., \& Guven, I. (2018).A Survey on ICT Usage and the Perceptions of Social Studies Teachers in Turkey. Educational Technology \&Society, 11(3); 37-51.

Islam (2017). ICT for Development and UISC: A Step to Alleviate Poverty in Rural Areas of Bangladesh. In Proceedings of the 7th International Conference on Theory and Practice of Electronic Governance (pp. 342-343). New York, NY, USA: ACM. doi:10.1145/2591888.2591950

Okello-Obura and Magara (2018). Computer and internet use by first year clinical and nursing students in a Nigerian teaching hospital. BMC Medical Informatics and Decision Making, 3(1); 10. doi:10.1186/1472-69473-10

Watson, D. M. (2001). Pedagogy before Technology: Rethinking the Relationship between ICT and Teaching. Education and Information Technologies, 6(4); 251-266. doi:10.1023/A:1012976702296. 